Mongolian Geoscientist

Original article

\title{
NEW OROGENIC TYPE GOLD OCCURRENCES IN THE UYANGA ORE KNOT (CENTRAL MONGOLIA)
}

\author{
Ariunbileg Sodov ${ }^{*}$, Olga Gaskova ${ }^{2,3}$, Altansukh Gankhuyag ${ }^{1}$, Dagva-Ochir Lkhagvasuren ${ }^{1}$, \\ Otgonbaatar Dorjsuren ${ }^{1}$, Oyunchimeg Tumen-Ulzii ${ }^{1}$, Battushig Altanbaatar ${ }^{1}$
}

\author{
${ }^{1}$ Department of Geology, Institute of Paleontology and Geology, Mongolian Academy of Sciences, Ulaanbaatar 15160, Mongolia \\ ${ }^{2}$ Sobolev Institute of Geology and Mineralogy Siberian Branch, RAS, Novosibirsk 630090, Russia \\ ${ }^{3}$ Department of Geological Processes Correlation, Division of Earth Sciences, Novosibirsk State University, Novosibirsk 630090, Russia \\ *Corresponding author.Email: ariunbilegsodov@yahoo.com
}

\section{ARTICLE INFO}

Article history:

Received 16 December 2018

Accepted 26 December 2018

\begin{abstract}
The Uyanga ore knot district of the Khangay metallogenic zone are hosted by the lower-middle Devonian volcanogenic-sedimentary Erdenetsogt formation. About 40 samples were collected from the host rocks, veins and quartz veins in the Uyanga ore knot district in 2016. The new Burgetei, Ult and Senjit gold occurrences were studied. The quartz-sulfide, gold-arsenic and gold-antimony-mercury mineralization are determined in the berecitization, silicification, limonitization and glauconization altered metasomatic zones within the Uyanga ore knot districts. The rocks of the Erdenetsogt formation have an irregular gold content: $0.96 \mathrm{~g} / \mathrm{t} \mathrm{Au}$ is determined in quartz vein taken from trench of the Burgetei occurrence (BG-7/16), Au content is highest up to $3.5 \mathrm{~g} / \mathrm{t}$ in the quartzite-jasper (Ult-7/16 and Ult-9/16) cut by quartz veins in the Ult occurrence. The Senjit occurrence represents Au-Hg-Sb epizonal level of orogenic gold deposits structure with highest $\mathrm{Hg}$ content up to $851 \mathrm{ppm}$. This year no sulfide minerals were found in the siltstone of this occurrence. The Au content of arsenical pyrite of the Burgetei and Ult is below the detection limit by electron microprobe analysis. The Au content of arsenopyrite of the Ult occurrence is highest (up to $238 \mathrm{ppm}$ ). Therefore, the ore-mineral assemblages in the gold occurrences reflect the differences between the three explored sites, formed in the course of fluid evolution during the fluid-rock interaction. Variable concentrations of indicative elements (As, $\mathrm{Te}, \mathrm{Sb}, \mathrm{Hg}$ ) and their ratios confirm this fact. The geodynamic position, the type of the hydrothermal alteration of both igneous and sedimentary rocks, textures and mineral assemblages, the mineralization sequences are consistent with orogenic classification for the Burgetei, Ult and Senjit gold occurrences.
\end{abstract}

Keywords: pyrite, arsenopyrite, oxidation, fluid-rock interaction

\section{INTRODUCTION}

The classical theory implies that orogenic $\mathrm{Au}$ deposits form during the late stage of orogeny and are typically hosted by rocks of greenschist to amphibolite metamorphic grade that may be spatially related to granitoid intrusions (Groves et al., 1998; Goldfarb et al., 2001). Consensus on even the most fundamental features of an orogenic gold system model, however, remains elusive (Wyman et al., 2016). According to

(C) The Author(s). 2018 Open access This article is distributed under the terms of the Creative Commons Attribution 4.0 International License (https://creativecommons.org/licenses/by/4.0/), which permits unrestricted use, distribution, and reproduction in any medium, provided you give appropriate credit to the original author(s) and source, provide a link to the Creative Commons license, and indicate if changes were made. 
(Goldfarb et al., 2001) orogenic gold-forming events continued to be extremely widespread during Paleozoic time along the extensive margins of both Gondwana and the PaleoTethys Ocean basin. Goldfarb, Groves (2015) have rewired the current models for orogenic gold formation: "Using the principle of Occam's razor that the hypothesis with the least number of assumptions is the best, the simplest, most elegant, universal model is that all orogenic gold deposits formed throughout time from devolatilization of oceanic crust and associated carbonaceous, sulfidic sediments with goldenriched pyrite late in the history of subduction when local plate motion was perturbed". Orogenic gold deposits can form over a variety of depths, from as shallow as $3 \mathrm{~km}$ to as deep as $20 \mathrm{~km}$, typically during late orogenic shifts from compressional to transpressional or transtensional regimes. Arsenopyrite and pyrite represent the most abundant sulphide minerals that occur in association with the $\mathrm{Au}$ mineralization, which formed from low salinity, $\mathrm{CO}_{2}$-bearing, reduced and near-neutral $\mathrm{pH}$ fluids that show a wide range in fluid temperatures from about 200 to $500^{\circ} \mathrm{C}$ (Goldfarb et al., 2005; Keith et al., 2018). A comparison of the above data of leading scientists of the world and obtained by us in recent years on new ore Mongolian gold occurrences made it possible to make an assumption about the genetic belonging of the latter.

The vast territory of Mongolia occupies a large part of the Central Asian Orogenic Belt (CAOB). The Khangay-Khentey belt is located in central Mongolia and records a progressive accretionary orogeny of the $\mathrm{CAOB}$ from the Middle Cambrian to the Early Mesozoic (Erdenesaikhan et al., 2013). The geology and petrology namely of the Khangay region were reported during 1:50 000 scale geological mapping (Lhundev et al., 1994). The primary ore occurrences of the Uyanga gold ore knot district of the Khangay gold zone are hosted in volcanogenic-sedimentary rocks of the lowermiddle Devonian Erdenetsogt formation (Fig. 1). The volcanogenic rocks are metamorphosed under greenschist facies condition The geochemical characteristics of Middle Paleozoic greenstones are of particular interest for understanding the geodynamic evolution of the Khangay belt. Orolmaa and other (2008) investigated the Permian-Triassic granitoid magmatism and metallogeny of the Khangay upland (Fedorova,1975). They have indicated that gold mineralization in the area that is confined within the Khangay gold belt appears to be independent of the granitoid intrusions.

Among other gold ore occurrences of unknown genesis, a group of gold-quartz vein mineralization such as Burgetei, Ult, Senjit, Huren Khoshuu were identified in the eastern tributary of the Ongi Gol river, along the Ovor Ult, Booroljuut rivers valley within the UltBooroljuut ore placer deposits of the Uyanga ore knot district in the Khangay gold metallogenic zone (Dejidmaa, 1996, 2012; Lhundev et al., 1994). The Uyanga group of primary gold occurrences are associated with the gold quartzsulfide mineralization in the hydrothermal metasomatisms of shear zones (Altanzul and Baasandorj, 2014, Khishgee and Akasaka, 2015).

In this paper, new information concerning the Burgetei, Ult, and Senjit gold occurrences of the Uyanga gold ore knot is presented. In terms of the geological conditions, mineral assemblages, chemical composition of ore minerals, ratios of indicator elements and isotopic investigation an assumption is made to clarify the genetic processes of the ore occurrences formation, because they are perhaps the typical orogenic gold occurrences. It is appropriate to refer to the opinion of Mongolian scientist: "All gold deposits of Mongolia belong to granite-related deposits, i.e. epithermal and orogenic gold deposits. Mineralization age of gold deposits depends on geodynamic condition of each specified area, however most significant genetic type among them is orogenic gold deposits (Delgertsogt, 2017).

\section{GEOLOGY OF THE STUDY AREA}

The study area is located in the southeast of the Tsetserleg turbidite accretion terrain in the Khangay-Khentey orogenic structure of the Mongol-Okhotsk fold belt (Fig. 1) (Tomurtogoo, 2002; 2008). Tsetserleg accretion terrain is composed of the lower-middle Devonian chertbasalt-sandstone Erdenetsogt, the middle-upper 
Devonian sandstone-siltstone Tsetserleg and the lower carboniferous polymictic sandstonesiltstone Dzargalant formations (Amantov et al., 1970; Tomorchodor et al., 1990; Lhundev et al., 1994; Tomurtogoo 2002; Badarch et al., 2002). These Paleozoic rocks are separated from each other mainly by thrust faults (Fig. 1c) of the UltBooroljuut gold ore-placer mineralization of the Uyanga ore knot district (Dejidmaa, 2012) within the Tsetserleg terrain in the KhangayKhentey orogenic system (Borisenko et al., 2006; Orolmaa et al., 2008).

Within this ore knot district, except the number of gold-placer deposits occurred along UltBooroljuut river valley, the primary occurrences of the Burgetei, Ult, Senjit gold-quartz veins are hosted in the lower-middle Devonian Erdenetsogt formation with various alteration zones (Togtokh et al., 1986; Lhundev et al., 1994). The chert-basalt layer of the lowermiddle Devonian Erdenetsogt formation hosting the above-mentioned gold primary occurrences conformably beds inside the terrigenic formation. The primary gold occurrence was subsequently metasomatized with alteration zones and with variable thickness in different gold occurrence and usually anticline folded together with terrigenic layer, cut by gabbrodiorite dykes (Lhundev et al., 1994).

A number of hydrothermal alterations (quartz



Figure 1. Geology and natural resource map of Ult area of the Uyanga district (c) (modified from Lhundev et al., 1994) Location of study area: Central Asia orogenic belt (a) Tsetserleg accretion terrain of Khangai-Khentei Orogenic Belt (b) (Tomurtogoo, 2012) 
veins, quartzite, mineralization belt of faults zone, hydrothermal altered rocks) were identified along the fault in the area of gold primary occurrences. The ore mineralization is accumulated mainly in quartz veins and zone of tectonic breccia. In the hydrothermal berezite altered rocks (quartz, carbonate, sericite, pyrite) of those zones, arsenopyrite, sometimes chalcopyrite, the inset and vein of galenite and sulfates have been identified in the goldmercury hosting fine grain sugar like quartzite in the jasper-volcanogenic-terrigenic layer of the Erdenetsogt formation (Lhundev et al., 1994). Ore bodies in gold occurrences are consists of gold-quartz, gold-sulfide-quartz ore associations. Therefore, gold primary occurrences of ore knot district have a complex structure and hosted in the lower-middle Devonian volcanogenic-terrigenous Erdenetsogt formation.

\section{SAMPLING AND ANALYTICAL METHODOLOGY}

This work used the field data sampled from the exploration trenches in the Burgetei, Ult and Senjit gold occurrences of the Uyanga ore knot district in 2016. About 40 rock samples were collected from the host rocks, veins and quartz veins. About 20 samples were analyzed for petrography, mineralogy and geochemical analysis. Minerals were separated into heavy and light fractions for mineralogical analysis. Microprobe analysis was carried out by electron scan microscope with Energy Dispersive X-ray Spectroscopy method (SEM-EDX) at the laboratory of substance analysis of the School of Geology and Mining Engineering, Mongolian University of Science and Technology. Binocular was used for the separation of pyrite and arsenopyrite monominerals from the other sulfide minerals. In addition, samples were analyzed by electron scan microscope LEO $01430 \mathrm{VP}$, by electron probe microanalyzer Camebax-Micro, JEOL JXA-8100 and atomabsorption methods in the V.S. Sobolev Institute of Geology and Mineralogy, SB RAS. Gold was determined according to the custom prepared method by electron-probe microanalyzer JEOL JXA- 8100 at $20 \mathrm{kV}$ and $200 \mathrm{nA}$ with the extended diameter of up to $10-15 \mathrm{~mm}$ electron beam. Gold analysis were carried out by atomic absorption spectrometer (AAS) with 55 AA Agilent instrument in the SGS-IMME Co Ltd., Mongolia, rare element analysis was carried out by ICP OES method with Optima 7300DV Perkin Elmer-pair inductive plasma spectrometer. Sulfur isotope analyses were carried out at the Multi-elemental and Isotope analysis CCA, V.S. Sobolev Institute of Geology and Mineralogy, SB RAS (Novosibirsk). The procedures overview is given in (Ariunbileg et al., 2016; Pal'yanova et al., 2016).

\section{RESULTS \\ Occurrences type and ore mineralization \\ Gold occurrence Burgetei $\left(46^{\circ}\right.$}

$\left.34^{\prime} 30.00^{\prime \prime} \mathrm{N} / 102^{\circ} 15^{\prime} 5.00^{\prime \prime} \mathrm{E}\right)$ is located in the valley of Burgetei and Ovor Burgetei slope junction, at the top of $2300 \mathrm{~m}$ watershed hill on the center of the NE-NW arched anticlinal fold of the volcanogenic-terrigenic Erdenetsogt formation. Siliceous rock layers of this formation with varying thick host basalt and its alteration zone is cross cut by NW stretched 0.5 $0.8 \mathrm{~m}$ thick microdiorite dykes, quartz veins and veinlets. Sericitization, berecitization, limonitization alteration of the Burgetei occurrence are well observed at 1, 2, 3 trenches which cross approximately in $200 \mathrm{~m}$ wide. Host sediments, basalt, diorite dyke and veins near the gold-bearing quartz veins of the Burgetei occurrence are all changed by the hydrothermalmetasomatic alteration (Lhundev et al., 1994). Surface weathering, erosion and oxidation intensity clearly shows metasomatic alteration zone.

The siltstone of volcanogenic-terrigenic Erdenetsogt formation cut veins and structures of metasomatic alteration; ore controlling transition zone with the brittle-ductile deformation is clearly seen in the second trench of the Burgetei occurrence (Fig. 2a). Deposits and occurrences of the orogenic gold are formed in such a type of structures, i.e. orogenic gold deposits are emplaced during collisional events throughout much of the middle to upper crust. Oxidized quartz veins $(1-10 \mathrm{~cm})$ and veinlets of the Burgetei well observed in the exploration trenches (sample BG-7/16 contain $0.86 \mathrm{ppm}$ of 
gold). Except (BG-1/16, BG-7/16), quartz, carbonate and iron oxides, ore minerals such as pyrite, antimonite and hematite are observed in the quartz veins $(1-10 \mathrm{~cm})$.

Carbonate altered (magnesite) metasomatic ring is observed within the basalt in outside of alteration zone that cut by quartz veins (Fig. 2b). Ore-bearing grey, cryptocrystallic crystal, altered rock (BG-2/16) is composed of sericite, limonite altered sericite, quartz, iron oxide and pyrite. The main body is composed of very small sericite aggregates that form dendritic like structures (Fig. 3), inside of which the cluster of iron oxide and completely oxidized pyrite relicts are observed. These small aggregate quartz veins with ore mineralization are distributed in a spherulite shapes with varying sizes.
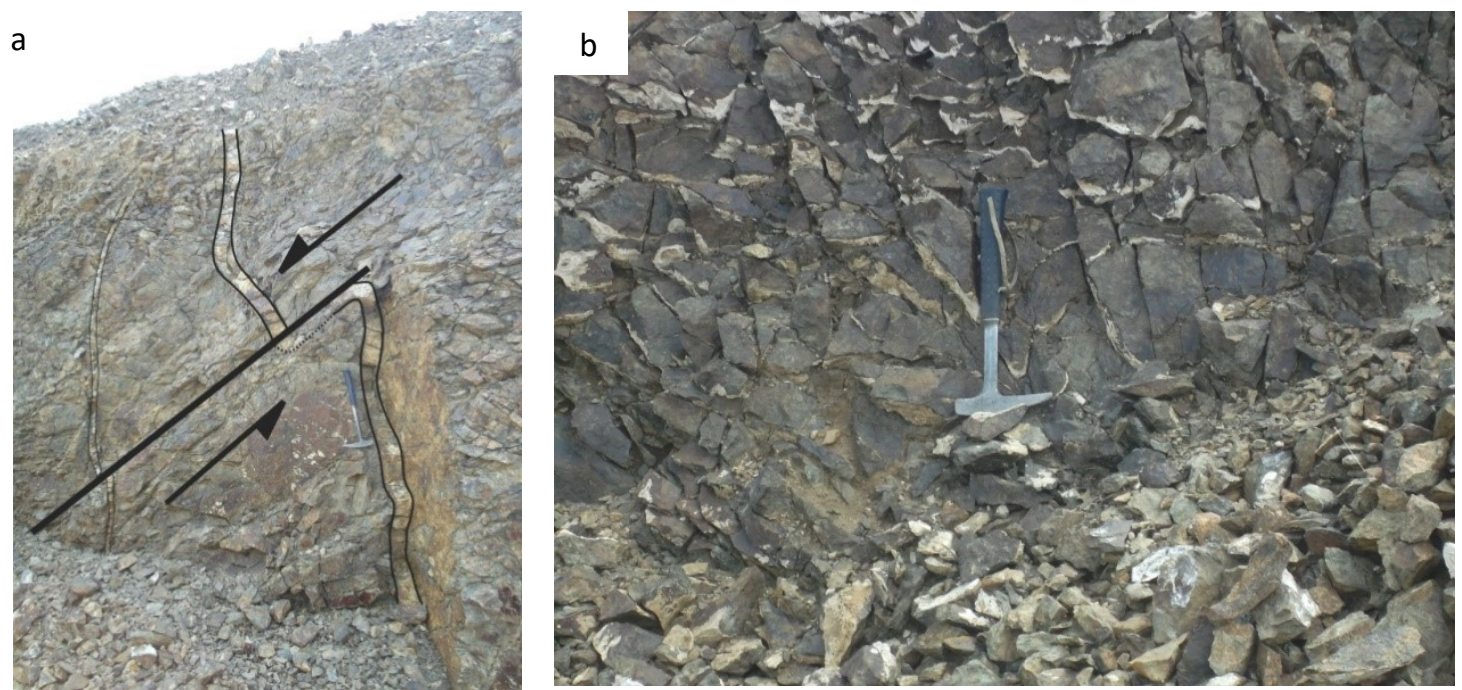

Figure 2. Transform fault of the brittle-ductile deformation of the quartz veins in the Burgetei exploration trench (a). Carbonate veinlets in the volcanites of the Burgetei occurrence trench (b)
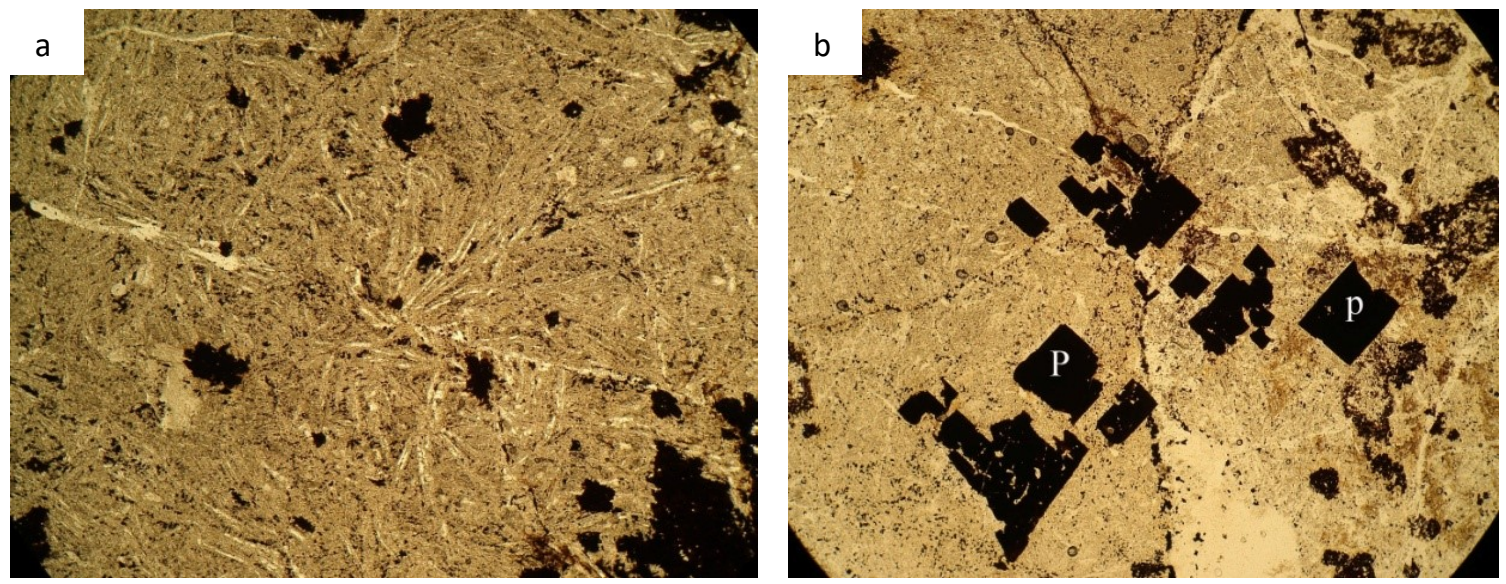

Figure 3. The growth of beam shaped sericite aggregate in the Burgetei, Sample BG- 2/16 (a) and sample BG-4/16 (b). P - Pyrite crystals

Mineralogical analysis of this sample identified the intense limonitization of chromite and serpentine. Therefore, it can be accepted by that the primary rock with limonitization and sericitization in the mineralization zone was basalt. Except the berecitization zone of the exploration trench (BG-3/16), the sericite, quartz, zircon and ore minerals composed from oxidized pyrite and arsenopyrite are observed inside the sheared and altered grey siltstone with the abundant iron oxide and cryptocrystalline in the brecciated, metasomatic zone. 
The sericitizated quartz metasomatite with pyrite (BG-4/16, Au content $0.02 \mathrm{ppm}$ ) are spread like veins and lens. Pyrite is almost not involved in the oxidation, it is in a good crystalline form, sometimes grouped into larger $(1.5-2.3 \mathrm{~mm})$ frame, and rutile granules are observed. Pyrite cube crystal aggregate of larger size are spread along the veins and fractures. Such ore minerals take less than $25-30 \%$ of total. These crystals are chosen for the microprobe study.

Dyke of granodiorite porphyry, microdiorite (BG-6/16, BG-8/16) is intensely altered, and composed of plagioclase $(60-65 \%)$, crystalline amphibole (20-25\%) and quartz (10-12\%). The main background part has a micro hypidiomorphic structure. They have partially and completely substituted by sericite, chlorite, carbonate, epidote aggregates. This indicates the berezite alteration of the granodiorite body in the Burgetei occurrence. Mineral association of the Burgetei occurrence are classified into high, low and without sulfide types.

Mineralogical analysis revealed the alteration minerals such as sericite, chlorite, muscovite, and $\mathrm{Fe}-\mathrm{Mn}$ carbonates, except the serpentine in the Burgetei volcanogenic rock samples. The SEM-EDS analysis identified ore minerals such as pyrite, antimonite and gold. The lowermiddle Devonian volcanic rocks of the Burgetei occurrence are intensely berecitizated and even barite and nickel arsenide were formed in some samples except the ilmenite, chromite, siderite, chlorite and sericite. The observed high content of the platinum group element iridium, except the monazite and xenotime in the sample, suggests its plume origin enriched by ocean tholeiitic basalt (Erdenesaikhan et al., 2013). By the influence of the metasomatic alteration, the microdiorite, granodiorite-porphyry dykes host the pyrite, carbonates, chlorite, monazite and xenotime.

Gold occurrence Ult $\left(46^{\circ} 34^{\prime} 55^{\prime \prime} / 102^{\circ} 17^{\prime} 20^{\prime \prime}\right)$ was observed in the east of hydrothermalmetasomatic alteration zone that stretches arching in NE-NW where the irregular distributed berecitization, pyritization and limonitization hosted in siliceous siltstone with the lower layer andesite-basalt, basalt layers of the lower-middle Devonian Erdentsogt formation (Lhundev et al., 1994).

Gold mineralization of the Ult occurrence is represented by the argillic altered dark siltstone were observed in fractured iron hat (gossan) formed from the sulfide oxidation on the exploration trench at the $2300 \mathrm{~m}$ altitude. It might be interpreted as pipe to the deep. This alteration associated with the mineralization is observed also in the jasper-quartzite-basalt formation. Small size quartz-sulfide veins are observed here. Microdiorite (Ult-1/16) is composed of plagioclase $50-55 \%$, quartz $15-$ $18 \%$ and secondary minerals (sericite-carbonatechlorite 25-30\%). Sometimes initial color minerals were completely substituted by carbonates, chlorite and iron oxides (Fig. 4).

The light grey (enriched by iron oxide), fine

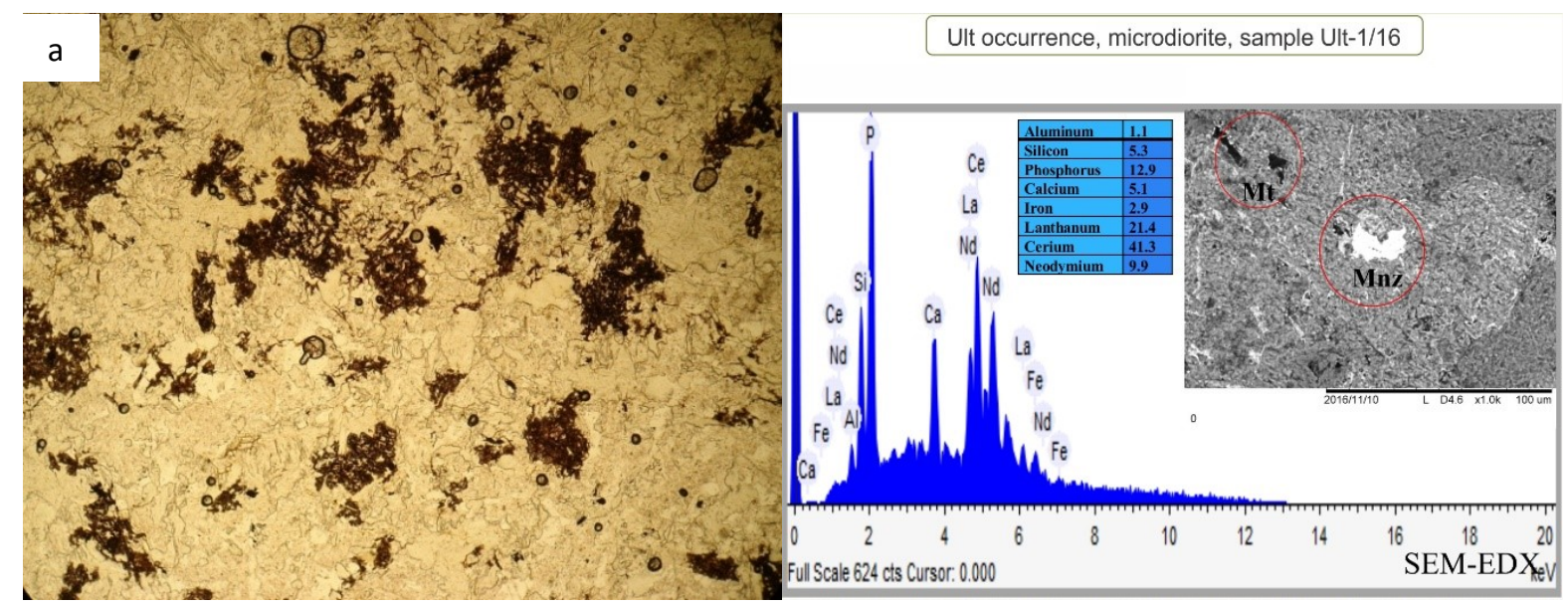

Figure 4. Metasomatized microdiorite sample Ult-1/16, magnification 40x (a). SEM-EDX- electron images, where Mn - and Mnz - monazite (b). 
grained sericite and argillic siltstone rock cut by quartz veins (Ult-2/16, Ult-5/16) contains quartz -sericite narrow veinlets. In addition, electron microscope analysis revealed quartz, barite and carbonate veins in it. It is composed of dark micro fauna (radiolaria), aleurolitic mass in argillic rock with pyrite, ore minerals - pyrite and arsenopyrite, hornblende and carbonates. Non-oxidized pyrites of the Ult occurrence are mainly observed in the siltstone and jasper.

In the Ult occurrence, the siltstone with intense metasomatic alteration, with argillic layers, quartzite, predominantly sericite, chlorite, carbonates and pyrite altered by berecitization in jasper, and rarely occur monazite and ilmenite in accessories minerals were formed as revealed by the scan electron microscope (SEM-EDX). Limonitization involved in the surface oxidation and predominantly $\mathrm{Cu}$ and $\mathrm{Zn}$ oxidation minerals.

Gold occurrence Senjit ( $\left.46^{\circ} 33^{\prime} 50^{\prime \prime} / 102^{\circ} 18^{\prime} 20^{\prime \prime}\right)$ is represented by the clayey schist, brecciation, and argillic alteration that are intensely developed along the NE directed transform fault inside the fine grain, green grey sandstonesiliceous siltstone branch of the Erdenetsogt formation. Moreover, volcanogenic rocks are altered to the green grey color glauconites $(\mathrm{Ca}$ hosting water alumosilicates). All these conditions suggest their formation in a shallow ocean environment. SEM-EDX analysis identified zircon and ilmenite. Scandium in the zircon mineral proves that alkali volcanogenic rock was involved to glauconite under the shallow ocean environment. For this gold ore occurrence, there is less information than the other two. However, it cannot be missed, since it represents a certain $\mathrm{Au}-\mathrm{Hg}-\mathrm{Sb}$ epizonal level (Goldfarb and Groves, 2015).

\section{Geochemical study}

Geochemical assay data processing was carried out on the Uyanga gold occurrences (Table 1). It is determined, that at the Burgetei, Ult, Senjit primary occurrences, the berecitization, pyritization, silicification, limonitization and diorite, granodiorite dykes in the siliceousvolcanogenic-terrigenic layers of the Erdenetsogt formation have an irregular gold content. For instance, $0.96 \mathrm{~g} / \mathrm{t} \mathrm{Au}$ is determined in quartz vein taken from trench of the Burgetei occurrence (BG-7/16). Au content is highest up to $3.42 \mathrm{~g} / \mathrm{t}$ in the quartzite-jasper (Ult-7/16) cut by quartz veins in the Ult occurrence, and 0.05 $0.12 \mathrm{~g} / \mathrm{t} \mathrm{Au}$ content is defined at the Senjit occurrence. Another sample Ult 9/16 similar to the Ult-7/16 was analyzed only for gold (not listed in the Table 1). It turned out that it contained $3.5 \mathrm{~g} / \mathrm{t}$ gold. Thus, the volcanogenicterrigenic layers of the Uyanga group occurrences altered by metamorphism and metasomatic processes contain visible content of $\mathrm{Au}$.

Relatively high content of As, $\mathrm{Sb}, \mathrm{Hg}, \mathrm{S}, \mathrm{Sc}, \mathrm{Cr}$, $\mathrm{Ni}, \mathrm{Co}, \mathrm{V}, \mathrm{Mn}, \mathrm{Mg}$, Fe that are accumulated in association with the gold mineralization in comparison with the clarke content of the metamorphic and magmatic rocks were defined in the volcanogenic-terrigenic layers of the Erdenetsogt formation (Table 1). The content of the above ore element is different.

For instance, the geochemical analysis revealed the high content of As in the Burgetei occurrence (532 ppm in BG-2/16) simultaneously with $\mathrm{Co}, \mathrm{Ni}$ and $\mathrm{Fe}$ (50 ppm, 152 pm and 10\% respectively). Although Bi and Te concentrations are below the detection limit of ICP MS, high content of $\mathrm{W}$ was detected in three of seven samples. Such an association of elements are consistent with the deeper-earlier formation of the Burgetei gold occurrence. Because the increased content of antimony was determined in the quartz vein (BG-7/16) and in the microdiorite-porphyrite (BG-8/16), the Burgetei could be attributed to the $\mathrm{Au}-\mathrm{As} \pm \mathrm{Sb}$ one. The microdiorite of the Burgetei and Ult occurrences are similar in the contents of $\mathrm{Mn}$, $\mathrm{Cr}, \mathrm{Fe}, \mathrm{Ni}$. At the same time, the highest contents of $\mathrm{Mn}, \mathrm{As}$ and $\mathrm{Au}$ are characteristic of the Ult tectonic structures with intensive metasomatic transformations, namely siltstone with sericitization, berecitization and limonitization (Ult-6/16) and quartzite-jasper (Ult-7/16). Because the increased content of mercury (up to $86 \mathrm{ppb}$ ) was determined in these two samples, the type of this ore occurrence could be attributed to the $\mathrm{Au}-\mathrm{As} \pm \mathrm{Hg}$ one. A distinctive feature of the Senjit siltstones is high $\mathrm{Sb}$ and $\mathrm{Hg}$ contents, namely 33-39 $\mathrm{g} / \mathrm{t}$ and 8.5- 


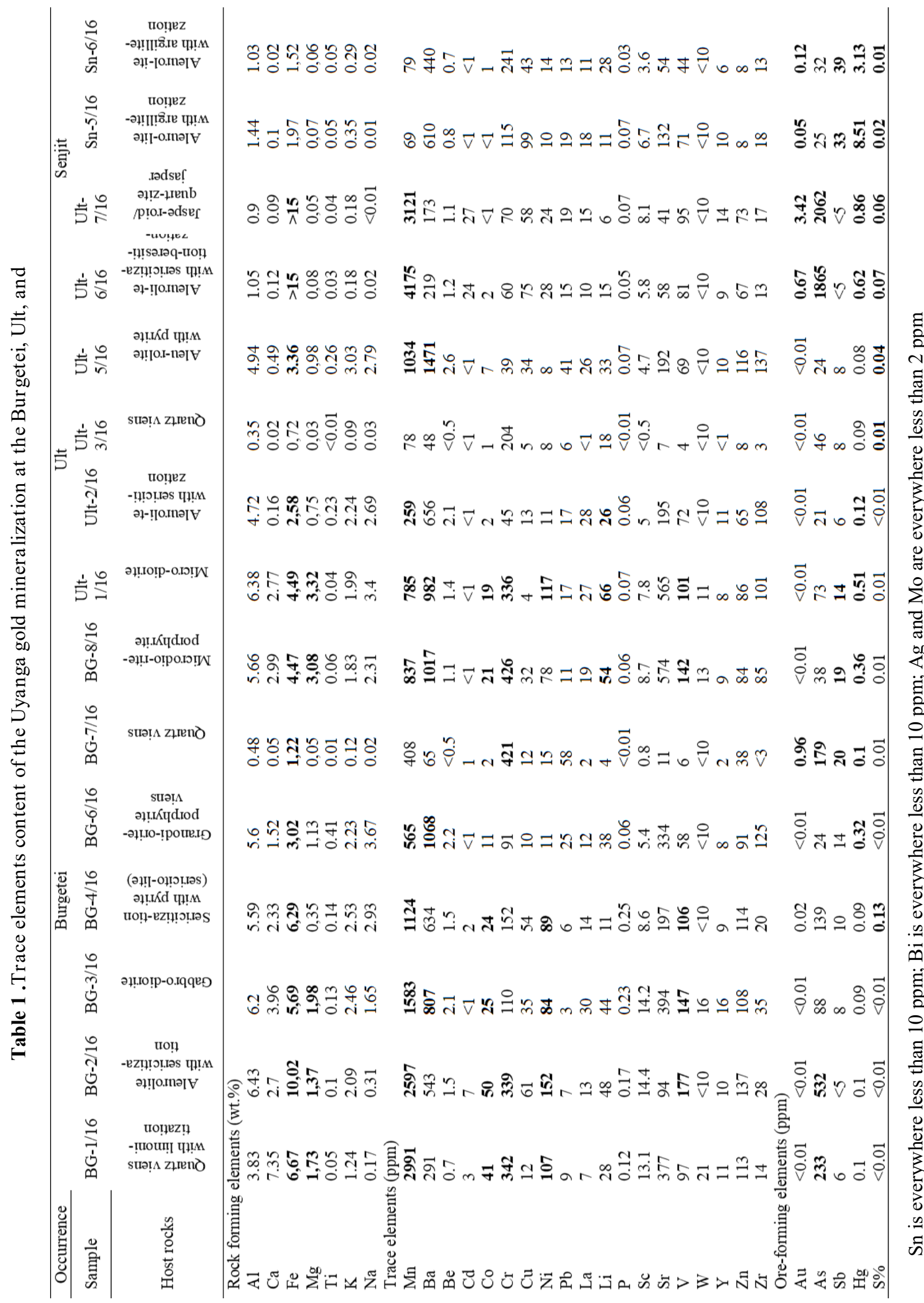



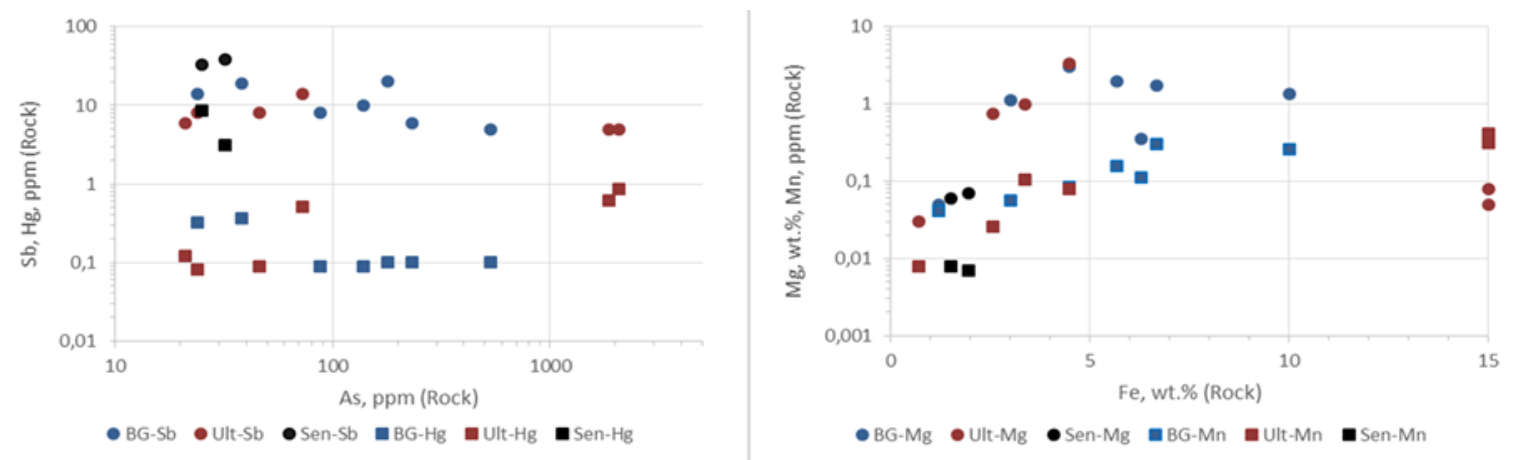

Figure 5. (a) Concentrations of $\mathrm{Sb}, \mathrm{Hg}$ vs. As and (b) $\mathrm{Mg}$, Mn vs. Fe in rocks of the Uyanga orogenic gold occurrences

$3.1 \mathrm{~g} / \mathrm{t}$ respectively. The $\mathrm{Au}-\mathrm{Hg}-\mathrm{Sb}$ association in the Senjit occurrences is taking place and present the epizonal part of the pluton (the shallowest zone). In the Senjit ore occurrence, a band of argillized rocks with gold-bearing quartz veins containing jasper are characteristic, but sulfide minerals were not found during in situ sampling. These results suggest, that ore element contents vary for each gold primary occurrences of the Uyanga gold mineralization knot depending on the type of metasomatites, amplitude of tectonic deformation and weathering grade.

As orogenic gold deposits are emplaced during collisional events throughout much of the middle to upper crust, the correlation of important elements is interesting. Fig. 5 shows the correlation of $\mathrm{As}$ and $\mathrm{Sb}$ (circles), $\mathrm{Hg}$ (squares) in the left part (A) and correlation of $\mathrm{Fe}$ and $\mathrm{Mg}$ (circles) or Mn (squares) in different rocks of the Uyanga ore knot.

There is no clear correlation between arsenic and mercury and antimony, rather one can see their almost constant contents with the increase for arsenic. In this case, the Ult occurrence is clearly distinguished by the highest arsenic in the rocks (and the highest gold content). Iron and $\mathrm{Mg}, \mathrm{Mn}$ correlate positively at low iron concentrations, at the highest $\mathrm{Fe}$, the correlation is weak. The Senjit occurrence with highest $\mathrm{Sb}$ and $\mathrm{Hg}$ versus low As contents just like low $\mathrm{Mg}$ and $\mathrm{Mn}$ versus low Fe content belongs to the top of the structure zone (black circles and squares, Fig. 5).

\section{Pyrite and arsenopyrite analysis}

Pyrite and arsenopyrite dominate in sulfide minerals composition of the Uyanga gold primary occurrence. Pyrite is stable under various physicochemical conditions and its refractory behavior to post-depositional metamorphism and its near-ubiquity makes it suitable for micro-analytical studies to reconstruct ore-forming processes through space and time (Keith et al., 2018). Assemblages containing arsenopyrite and arsenical pyrite are common in orogenic gold deposits formed at greenschist facies conditions. Gold is observed in both minerals but is more abundant in arsenopyrite. The fact that measured values in arsenopyrite and pyrite differ by two orders of magnitude is concordant with empirical evidence for incorporation of greater amounts of $\mathrm{Au}$ into arsenopyrite relative to pyrite (Cook et al., 2013). Chemical composition of pyrites of the Burgetei and Ult ore occurrences are shown in Table 2.

As shown in Table 2, the $\mathrm{S}$ content in pyrites varies from 51.4 to $53.0 \mathrm{wt} . \%$, with a mean of 52.67 wt.\% (Burgetei) and from 51.19 to 52.85 wt.\%, with a mean of $52.40 \mathrm{wt} \%$ (Ult). The S contents of most of the samples are lower than the theoretical values (53.45 wt\%). Hence, As-S substitution apparently occurs in pyrite. From all the analyzed trace-elements the highest As impurity (6.5 wt.\%) was observed in the tabular pyrites of the Ult occurrence (as in its wall rocks). The high As content there is in the Burgetei occurrence (4.4 wt.\%) simultaneously with highest $\mathrm{Ni}(445 \mathrm{ppm})$ and $\mathrm{Sb}(81 \mathrm{ppm})$ contents. The concentration of gold in the studied pyrites is below the detection limit, specified in Table 3 (78 ppm). Arsenical pyrite is of great environmental interest because its 
Table 2. Pyrite chemical composition of the Burgetei and Ult

\begin{tabular}{|c|c|c|c|c|c|c|c|c|c|c|c|}
\hline $\begin{array}{l}\text { Element/ } \\
\text { Occurrence }\end{array}$ & & $\begin{array}{c}\mathrm{Fe} \\
\text { wt.\% }\end{array}$ & $\begin{array}{c}\mathrm{S} \\
\text { wt.\% } \\
\end{array}$ & $\begin{array}{c}\mathrm{Ni} \\
\mathrm{ppm}\end{array}$ & $\begin{array}{c}\mathrm{Cu} \\
\mathrm{ppm}\end{array}$ & As ppm & $\begin{array}{c}\text { Se } \\
\text { ppm }\end{array}$ & $\begin{array}{c}\text { Te } \\
\text { ppm }\end{array}$ & $\begin{array}{c}\mathrm{Bi} \\
\mathrm{ppm}\end{array}$ & $\begin{array}{c}\mathrm{Sb} \\
\mathrm{ppm}\end{array}$ & $\begin{array}{c}\mathrm{Au} \\
\mathrm{ppm}\end{array}$ \\
\hline \multirow{3}{*}{ Burgetei $n=60$} & Min & 43.76 & 51.4 & n.d. & n.d. & n.d. & n.d. & 45 & n.d. & n.d. & n.a. \\
\hline & Max & 46.91 & 53.01 & 5735 & 297 & 12900 & 348 & 589 & 1171 & 357 & n.a. \\
\hline & Mean & 46.39 & 52.67 & 445.18 & 52.85 & 4411.5 & 81.62 & 325.1 & 166.35 & 81.61 & n.a. \\
\hline \multirow{3}{*}{ Ult $n=30$} & Min & 45.61 & 51.19 & n.d. & n.d. & 1513 & n.d. & 59 & n.d. & n.d. & n.a. \\
\hline & Max & 46.69 & 52.85 & 1207 & 292 & 23400 & 409 & 597 & 1212 & 130 & n.a. \\
\hline & Mean & 46.43 & 52.40 & 114.7 & 96.2 & 6553.13 & 78.43 & 343 & 312.03 & 6.27 & n.a. \\
\hline
\end{tabular}

Table 3. Arsenopyrite chemical composition of the Ult occurrence

\begin{tabular}{|c|c|c|c|c|c|c|c|c|c|c|c|c|}
\hline $\begin{array}{c}\text { Element / } \\
\text { Occurrence }\end{array}$ & & $\begin{array}{c}\text { Fe, } \\
\text { wt. } \%\end{array}$ & $\begin{array}{c}\mathrm{S} \\
\mathrm{wt}, \%\end{array}$ & $\begin{array}{c}\text { As, } \\
\text { wt. } \%\end{array}$ & $\begin{array}{l}\mathrm{Ni}, \\
\mathrm{ppm}\end{array}$ & $\begin{array}{l}\mathrm{Cu}, \\
\mathrm{ppm}\end{array}$ & $\begin{array}{l}\mathrm{Se}, \\
\mathrm{ppm}\end{array}$ & $\begin{array}{l}\text { Te, } \\
\text { ppm }\end{array}$ & $\begin{array}{l}\mathrm{Bi}, \\
\text { ppm }\end{array}$ & $\begin{array}{l}\mathrm{Sb}, \\
\mathrm{ppm}\end{array}$ & $\begin{array}{l}\mathrm{Au}, \\
\mathrm{ppm}\end{array}$ & $\begin{array}{l}\mathrm{Ag} \\
\mathrm{ppm}\end{array}$ \\
\hline \multirow{3}{*}{ Ult $(n=13)$} & Min & 33.65 & 18.98 & 45.41 & n.d. & n.d. & n.d. & 264 & 268 & n.d. & n.d. & n.d. \\
\hline & Max & 34.13 & 19.86 & 47.1 & 3043 & 307 & 513 & 1124 & 3146 & 293 & 238 & 10 \\
\hline & Mean & 33.85 & 19.54 & 45.97 & 293.9 & 41.54 & 216.1 & 661.5 & 1911 & 59.54 & 107.9 & 1,5 \\
\hline
\end{tabular}

( $n=$ number of analyses; $n . d .=$ not detected; $n . a .=$ not analysed $)$

oxidative dissolution can release significant amounts of As and trace metals into the environment.

Orogenic Au pyrite has intermediate Te and Se contents but characteristically shows a significant Te variation over a small range of Se (Keith et al., 2018, Deditius et al., 2014). It should be noted that in the ore occurrences of the Burgetei and Ult, the contents of Te and Se and, accordingly, their ratios are very similar $0.24 \pm 0.1$ (Fig. 4). The average content of Te (325 - $343 \mathrm{ppm}$ ) corresponds to the tellurium of reference world wild orogenic gold deposits. The question of the tellurium incorporation in pyrite requires further study. It can be controlled by the crystal-chemical properties of pyrite (solid solutions) or due to the telluride inclusions.

Trace-element content (Te, $\mathrm{Se}, \mathrm{Bi}, \mathrm{Sb}, \mathrm{Cu}, \mathrm{Au}$, $\mathrm{Ag}$ ) in the arsenopyrite is quite different. Since gold was clearly detected in arsenopyrite, a detailed electron probe microanalysis (13 points) of arsenopyrite of the Ult-samples from quartz vein was performed. This analysis shown limited variation with respect to Fe:As:S ratio. At the same time, the average gold content in recrystallized, coarse-prismatic arsenopyrite is
$108 \mathrm{ppm}$ with a maximum of $238 \mathrm{ppm}$, and minimum $0 \mathrm{ppm}$. Tellurium content reaches of $0.11 \mathrm{wt} . \%$ in the arsenopyrite. The high concentration of $\mathrm{Bi}$ (up to $0.3 \mathrm{wt} . \%$ ) and $\mathrm{Se}$ (up to 0.05 wt. \%) is characteristic of arsenopyrite, but silver is detected only in two points (103 and $97 \mathrm{ppm})$.

The concentrations and ratios of As and $\mathrm{Se}, \mathrm{Te}$ could be used to infer ore-forming processes. However, the mechanisms controlling the distribution of $\mathrm{Te}$ and $\mathrm{Se}$ are not understood well enough (Cook et al., 2013; Keith et al., 2018). Belousov and co-authors data (Belousov et al., 2018) on pyrite indicate two end-member associations in orogenic gold deposit ores: $\mathrm{Au}-$ As ores (pyrite $\mathrm{As} / \mathrm{Te}>200$ ) and $\mathrm{Au}-\mathrm{Te}$ ores (pyrite As/Te $<10$ ). Undoubtedly, the discussed gold ore occurrences are of the first type.

Diagrams in Fig. 6 show the concentrations of Te and Se vs. As in some interesting pyrites and arsenopyrite of the studied occurrences. Significant amount of the thin needle-like pyrites contains $\mathrm{Te}$ in the range of $0.004-0.06$ wt.\%; much more tellurium is found in arsenopyrite, the range is $0.03-1.1 \%$. Not all the samples studied contain selenium, but all of the above with respect to tellurium also applies to 

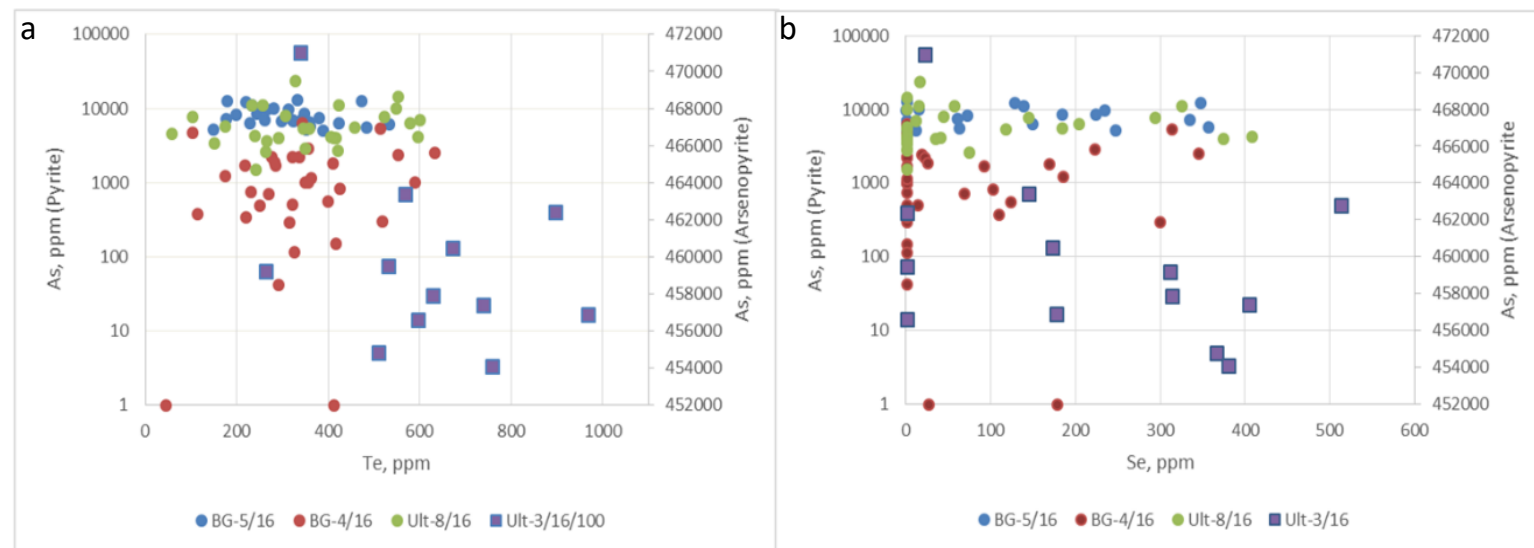

Figure 6. Concentrations of (a) Te and (b) Se vs. As in pyrite (left axis) and arsenopyrite (squares, right axis) from orogenic Au occurrences

the selenium-arsenic relationship. More high concentration of As is observed in the majority of prismatic pyrite crystals from the BG-5/16 (quartz vein) and Ult-8/16 (volcanic metasomatite with jasper and silicification) in comparison with the BG-4/14 (sericite with pyrite). There is no correlation between the content of arsenic and Te. In the arsenopyrite of Ult-3/16 sample (quartz vein) an inverse correlation is observed, which is very characteristic of orogenic gold deposits.

The area in the form of a rectangle is limited by the contents of Te of 200-600 ppm and As of $100-10000$ ppm. Keith et al. (2018) proposed that the association of Te and As is controlled by the crystal-chemical properties of pyrite due to their preferential incorporation on the $\left(\begin{array}{lll}1 & 1 & 0\end{array}\right)$ surfaces in the cubic crystal system. It is noteworthy that some orogenic Au pyrites show elevated Te concentrations and therefore those pyrites host telluride inclusions. The black dashed line in Fig. 3a of the paper above defines the solubility limit for Te solid solution in pyrite as a function of As, which is based on the equation presented by Reich et al. (2005) for the $\mathrm{Au}$-As system. Tellurium concentrations above the solubility line indicate telluride inclusions in pyrite, e.g. at $10,000 \mathrm{ppm}$ of As, Te should be low than $200 \mathrm{ppm}$. Selenium most likely occurs in solid solution in the corresponding pyrites due to isovalent $\mathrm{S}$ substitution. No systematic correlation exists between As and Se in pyrite and arsenopyrite.

\section{DISCUSSION}

Sulfide minerals are important indicators of hydrothermal mineralization, and the stable isotopes of sulfur offer a useful tool to constrain the origins of sulfide (Kresse et al., 2018). Although the total sulfur isotopic composition is influenced by temperature, $\mathrm{pH}$ value, oxygen fugacity and ion activity, the study of sulfur isotope abundances gives an idea regarding the modes of formation and subsequent histories of sulfur bearing materials. The isotopic content analysis of sulfur in pyrites from Ult-5/16 sample (siltstone with pyrite) and Ult-9/16 sample (quartzite-jasper, Au-content is $3.5 \mathrm{~g} / \mathrm{t}$ ) shows the mantle origin of Uyanga mineralization: $\delta^{34} \mathrm{~S}$ is $-6.94 \%$ and $-0.91 \%$ respectively. The ranges of $\delta^{34} \mathrm{~S}$ values found in nature for a number of different forms of sulfur are referenced in (Thode, 1970; Brueckner et al. 2014). Different forms of sulfur-bearing materials such as basic sills, primary igneous rocks and volcanic gases show distinctly narrower ranges of ${ }^{34} \mathrm{~S}$ values, which tend to be disposed symmetrically about zero. This distinction provides a basic diagnostic tool in sulfur isotope geochemistry of the Uyanga ore mineralization. Recent data (Ward et al., 2017) have revealed that the sulfur isotope composition has a $\delta^{34} \mathrm{~S}$ range of -7.7 to $+9.8 \%$ during formation of the Wallaby orogenic gold deposit. Given that changes in $\mathrm{pH}$ or temperature are minimal, all changes in sulfur isotope and trace element concentrations can be attributed to changes in oxygen fugacity. The 
increasing in $\delta^{34} \mathrm{~S}$ is most likely due to a reduction in oxygen fugacity. It was suggested by (Ward et al., 2017) from observations, that next generation of pyrite has a higher $\delta^{34} \mathrm{~S}$, and rims of pyrite grains have a lower $\delta^{34} \mathrm{~S}$ then a core. Moreover, they have discovered similarities between the rims of pyrite generation 1 crystals and the cores of pyrite generation 2 crystals.

Host sediments of the Uyanga ore knot, basalt, (grano) diorite dykes and other rocks are all changed by the hydrothermal-metasomatic alteration near the gold-bearing quartz veins. Surface weathering, erosion and oxidation intensity clearly shows metasomatic alteration zone. Sometimes initial rock-forming color minerals were completely substituted by carbonates, chlorite and various iron oxides. Limonitization is involved in the surface oxidation of the $\mathrm{Cu}$ and $\mathrm{Zn}$ minerals. Nevertheless, non-oxidized pyrites sometimes were observed both in the siltstone jasper and in the zones of sericitization. Pyrite cube crystal aggregates spread along the veins and fractures. Thus, we were able to distinguish two generations of pyrite. Further data for sulphides from orogenic gold occurrences would be required to fully evaluate the importance of Devonian metamorphic fluid contributions to the sulfur isotope budget of the Uyanga ore knot.
The ore mineralization is accumulated mainly in quartz veins and zone of tectonic breccia. In the Uyanga gold ore knot, pyrite and arsenopyrite are the most abundant sulfides during the ore forming stage in comparison with chalcopyrite, galena and sphalerite. It indicates that the mineral association of the three new occurrences is relatively simple. Chalcopyrite was identified in the berezite altered rocks, the inset and vein of galena and sulfates have been found in the gold-mercury fine grain sugar like jasperquartzite. Within the ore-controlling zone with brittle-ductile deformation, ore minerals such as antimonite and hematite were observed in the quartz veins and even barite and nickel arsenide were found in some samples. It is widely known that $\mathrm{Au}$ concentrations are generally correlate with As in arsenical pyrite, but gold concentration in the studied pyrites was observed below the detection limit by electron microprobe, therefore not given in the paper. Consistently detectable gold in arsenical pyrite should be determined by LA-ICP-MS (Cook et al., 2013).

To better understand the relationship between bulk metasomatite rocks vs. sulfide minerals chemistry, a triangle diagram showing Co-AsSb-contents of host rocks was constructed (Fig. 7). Siltstones from the Senjit occurrence is generally enriched in $\mathrm{Sb}(\mathrm{Hg})$ (blue squares), As tends to show higher and lower contents in the

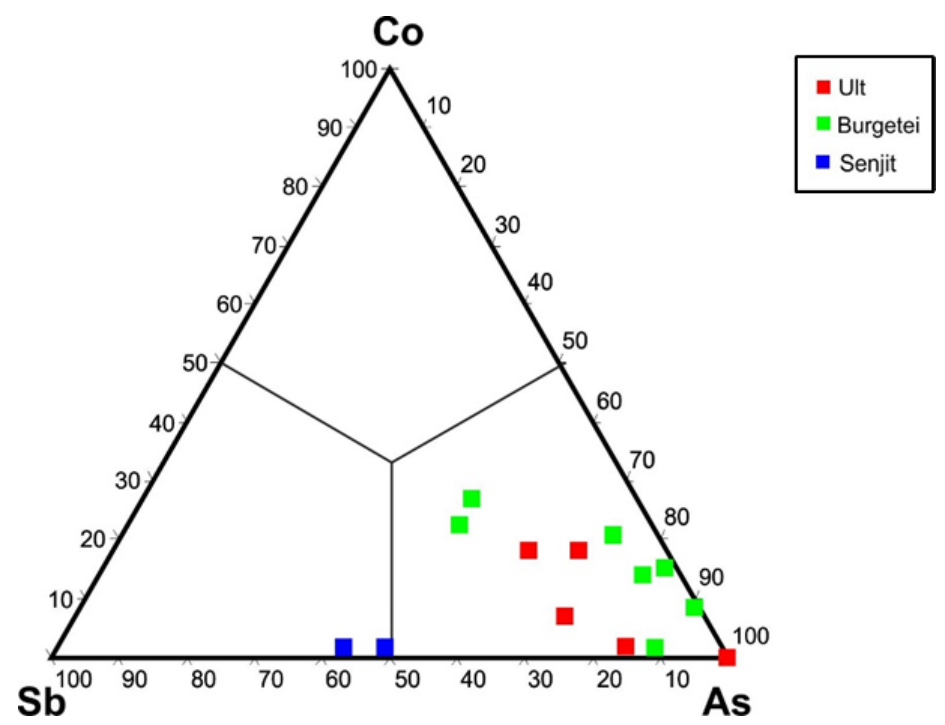

Figure 7. Compositions of the metasomatic alteration rocks at the three gold occurrences of the Uyanga ore district as a triangle diagram showing indicative elements 
Burgetei occurrence (green squares), some rocks of the Ult do not contain $\mathrm{Co}$ and $\mathrm{Sb}$ (below the detection limit) and high content of gold (red squares and diamond in the angle As).

The most notable changes from the Burgetei to the Ult pyrites chemistry are increase in As concentrations $(0.44$ and 0.65 wt. $\%)$, gradual increase in $\mathrm{Cu}$, Bi concentrations, and decrease in $\mathrm{Ni}, \mathrm{Sb}$ contents. The first increasing (As) mirror the fact that under more reduced conditions pyrite enrichment in As is connected with the replacement of the $\mathrm{S}$ atoms by As. There is no significant correlation between the content of arsenic and $\mathrm{Te}$ in pyrite. In the arsenopyrite of Ult-3/16 sample (quartz vein) an inverse correlation is observed, which is very characteristic of the orogenic gold deposits.

Recent data on the geodynamic conditions of the Khangay-Khentey orogenic structure, wall rock alteration and metasomatite composition of the Uyanga gold ore knot, mineral assemblages, chemical compositions of sulfide minerals including characteristic set of impurities ( $\mathrm{Se}, \mathrm{Te}$, $\mathrm{Sb}, \mathrm{Hg}$ ) in conjunction with the detailed review and analysis of the references below, allowed us to attribute three primary occurrences to the orogenic $\mathrm{Au}$. The varying content of ore elements such as $\mathrm{As}, \mathrm{Sb}, \mathrm{Hg}, \mathrm{S}$ indicates the different erosion level of ore formation: $\mathrm{Au}$ $\mathrm{As} \pm \mathrm{Sb}$ Burgetei, $\mathrm{Au}-\mathrm{As} \pm \mathrm{Hg}$ Ult and $\mathrm{Au}-\mathrm{Hg} \pm \mathrm{Sb}$ occurrences. This is evidenced by variations in the content of $\mathrm{Co}, \mathrm{Ni}, \mathrm{Fe}, \mathrm{Mn}, \mathrm{W}$ that are characteristic for the deeper hypozonal horizon.

Fluid sources and gold deposition mechanisms could be discussed only tentatively. It was suggested that ore mineralization from the three new gold occurrences has been formed via a gradual change in redox conditions within an evolving fluid. Probably the desulfidation took place too at the final stage (the sulfide minerals are very rare at the Senjit occurrence). The intensive fluid-rock interaction in the KhangayKhentey mobile orogenic area established the conditions required to igneous and metamorphic Fe-minerals oxidation, (hydr) oxides, chlorite and carbonates precipitation. The relative abundance of $\mathrm{Fe}$ (hydr) oxide minerals in the Uyanga host rocks confirm this idea. Negative $\delta^{34} \mathrm{~S}$ isotope values are common in oxidizing environments. This oxidizing environment destabilize Au-bisulfide complexes and trigger gold deposition.

\section{CONCLUSIONS}

The primary ore occurrences of the Uyanga gold ore knot district of the Khangay gold zone are hosted in volcanogenic-sedimentary rocks of the lower-middle Devonian Erdenetsogt formation. New information on the Burgetei, Ult, and Senjit gold occurrences of the Uyanga gold ore knot is presented.

The ore mineralization of these occurrences is accumulated mainly in zones of tectonic breccia and quartz veins, pyrite and arsenopyrite are the most abundant sulfides in comparison with chalcopyrite, antimonite, galena and sphalerite. Intensively oxidized and non-oxidized pyrites of different stages were distinguished confirming the variation in oxidation conditions.

The content of metalloids (As, $\mathrm{Sb}, \mathrm{Te}$ ), transition metals $(\mathrm{Hg}$ and iron group elements $\mathrm{Mn}, \mathrm{Fe}, \mathrm{Co}, \mathrm{Ni}$ ) increases in ore bodies of Uyanga gold primary occurrences. The contents of $\mathrm{Cu}, \mathrm{Pb}, \mathrm{Zn}$ and $\mathrm{Sn}$ are lower than average content of earth crust. This is the distinct geochemical characteristic of the orogenic gold type deposit (Eilu and Groves, 2001; Eilu et al., 2011). Highest gold content was determined (up to $3.5 \mathrm{~g} / \mathrm{t}$ ) in the quartzite-jasper with limonitization of the Ult occurrence cut by numerous small quartz veins and in arsenopyrites of this occurrence (238 ppm).

It was suggested that ore mineralization from the three new gold occurrences has been formed via a gradual change in redox conditions. Because negative $\delta^{34} \mathrm{~S}$ isotope values are common in oxidizing environments, this environment destabilizes Au-bisulfide complexes and trigger gold deposition.

\section{ACKNOWLEDGEMENT}

The authors would like to express their great gratitude to Dr. G. Dejidmaa and Dr. D. Orolmaa for their valuable assistance and participation in the 2016 fieldwork, conducted by the Institute in the framework of the research project named as "Geodynamic settings and structural criteria of gold mineralization in the Khangay-Khentey Orogenic Belt". This study was conducted partially (OLG) under the State 
assignment projects of IGM SB RAS (№ 03302016-0001). We thank the anonymous referees for their useful comments.

\section{REFERENCES}

Altanzul, Ch., Baasandolgorj, L., 2014. Structural characteristic of the Gatsuurt primary gold deposit, Mongolia. Haiguulchin, 50, 169-182 (in Mongolian)

Ariunbileg, S., Gaskova, O., Vladimirov, A., Battushig, A., Moroz E., 2016. Spatial Distribution of Uranium and Metalloids in Groundwater near sandstone-type uranium deposits, Southern Mongolia. Geochemical Journal 50(5), 393-401. https:// www.terrapub.co.jp/journals/GJ/ abstract/5005/50050393.html

Badarch, G., W. D., Cunningham, W.D. and Windley, B.F., 2002. A new terrane subdivision for Mongolia: implications for the Phanerozoic crustal growth of Central Asia. Journal of Asian Earth Sciences. 21(1), 87-110.

Borisenko, A.S., Naumov E.A., Obolensky A.A., 2006. Types of gold-ore deposits and conditions of formation. Geology and Geophysics. 47(3), 342-354 ( in Russian)

Brueckner, S.M., Piercey, S.J., Layne, G.D., Piercey, G., Sylvester, P.J., 2014. Variations of sulphur isotope signatures in sulphides from the metamorphosed Ming $\mathrm{Cu}(-\mathrm{Au})$ volcanogenic assive sulphide deposit, Newfoundland Appalachians, Canada. Mineralum Deposita, 50(5), 619-640.

Cook, N.J., Ciobanu, C.L., Meria, D., Silcock, D., Wade, B., 2013. Arsenopyrite-pyrite association in an orogenic gold ore: Tracing mineralization history from textures and trace elements. Economic Geology. 108, 1273 1283.

Deditius, A.P., Reich, M., Kesler, S.E., Utsunomiya, S., Chryssoulis, S.L., Walshe, J., Ewing, R.C., 2014. The coupled geochemistry of $\mathrm{Au}$ and $\mathrm{As}$ in pyrite from hydrothermal ore deposits. Geochimica et Cosmochimica Acta 140, 644-670.

Dejidmaa, G., 1996. Gold metallogeny of Mongolia. Mongolian Geoscientist. 1, 6-29.

Dejidmaa, G., 2012. Gold deposits: Geology and mineral resources of Mongolia, Vol. VI,
215-264 (in Mongolian).

Delgertsogt, B., 2017. Preliminary research results on metallogeny of Mongolia. Mongolian Geoscientist, 45, 290-292 (in Mongolian).

Eilu, P., Ojala, V.J., and Sarala, P., 2011. Exploration for orogenic gold deposits - with emphasis on geochemical exploration in glaciated Precambrian terrain. Workshop in the 25th International Applied Geochemistry Symposium 2011 22-26 August 2011 Rovaniemi, Finland, Vuorimiesyhdistys, B92 $-6,88$ pages.

Eilu, P., Groves, D.I., 2001. Primary alteration and geochemical dispersion haloes of Archaean orogenic gold deposits in the Yilgarn Craton: the pre-weathering scenario. Geochemistry: Exploration Environment, Analysis. 1(3), 183-200. https:// doi.org/10.1144/geochem.1.3.183

Erdenesaikhan, G., Ishiwatari, A., Orolmaa, D., Arai, S. and Tamura, A., 2013. Middle Paleozoic greenstones in the Hangay region, central Mongolia: Remnants of an accreted oceanic plateau and forearc magmatism. Journal of Mineralogical and Petrological Sciences. 108, 303-325.

Fedorova, M.E., 1975. Geological position and granitoid petrology of Khangay upland. Transaction of Joint Soviet-Mongolian Scientific Research Geological Expedition. 21 (in Russian).

Goldfarb, R.J., Baker, T., Dube, B., Groves, D.I., Hart, C.J., Gosselin, P., 2005. Distribution, character, and genesis of gold deposits in metamorphic terranes. Economic Geology. 100, 407-450.

Goldfarb, R.J., Groves, D.I., 2015. Orogenic gold: Common or evolving fluid and metal sources through time. Lithos, 233, 2 - 26.

Goldfarb, R.J., Groves, D.I., Gardoll, S., 2001. Orogenic gold and geologic time: A global synthesis. Ore Geology Reviews, 18, 1-75.

Gombosuren, B., Cunningham, W.D., Windley, B.F., 2002. A new subdivision for Mongolia: implications for the Phanerozoic crustal growth of Central Asia. Journal of Asian Earth Sciences 21, 88-110.

Groves, D.I., Goldfarb, R.J., Gebre-Mariam, H., Hagemann, S.G., Robert, F., 1998. Orogenic 
gold deposits - a proposed classification in the context of their crustal distribution and relationship to other gold deposit types. Ore Geology Reviews. 13, 7-27.

Keith, M., Smith, D.J., Jenkin, G.R.T., Holwell, D.A., Dye M.D., 2018. A review of Te and Se systematics in hydrothermal pyrite from precious metal deposits: Insights into oreforming processes. Ore Geology Reviews, 96, 269-282.

Khishgee, C., Akasaka, M., 2015. Mineralogy of the Boroo Gold Deposit in the North Khentei Gold Belt, Central Northern Mongolia. Resource Geology. 65(4), 311327.

Klemm, D.D., 1965. Synthesis und analysis in den Dreiecksdiagrammen FeAsS-CoAsSNiAsS und $\mathrm{FeS}_{2}-\mathrm{CoS}_{2}-\mathrm{NiS}_{2}$. Neues Jahrb. Mineral. Abh. 103(3), 205-221.

Kresse, C., Lobato, L.M., Hagemann, S.G., Silva, R.C.F., 2018. Sulfur isotope and metal variations in sulfides in the BIF-hosted orogenic Cuiabá gold deposit, Brazil: Implications for the hydrothermal fluid evolution. Ore Geology Reviews, 98, 1-27.

Lhundev, Sh., Tomurchudur, Ch., Purevdorj, Z., Baaday, D., Unurjav, L. and Ganbold, Yu., 1994. Geology and mineral resources of the Uyanga area 1:50000. Geological mapping and prospecting report 4756, 619 p. Ulaanbaatar, Mongolia. (in Mongolian)

Orolmaa, D., Erdenesaikhan G., Borisenko, A.S., Fedoseev, G.S., Babich, V.V., Jmodik, S.M., 2008. Permian-Triassic granitoid magmatism and metallogeny of the Hangayn (Central Mongolia). Russian Geology and Geophysics. 49, 534-544.

Pal'yanova, G.A., Sobolev, E.S., Reutsky, V.N., Bortnikov, N.S., 2016. Upper Triassic pyritized bivalve mollusks from the Sentachan orogenic gold-antimony deposit, eastern Yakutia: Mineralogy and sulfur isotopic composition. Geology of Ore Deposits. 58(6), 456-464.
Reich, M., Kesler, S.E., Utsunomiya, S., Palenik, C.S., Chryssoulis, S.L., Ewing, R.C., 2005. Solubility of gold in arsenian pyrite. Geochimica et Cosmochimica Acta. 69, 2781 -2796 .

Thode, H.G., 1970. Sulfur isotope geochemistry and fractionation between coexisting sulfide minerals. Mineralogical Society of America Special Paper. 3, 133-144.

Togtokh, D., Gurtsoo S., Lhundev, Sh. 1986. Report on 1:200000 geological survey carried out by Gurvansaikhan group No. II in 1982-1984 (in Russian).

Tomorchodor Ch., Ganbat L., Noosoy Z., Enkhsaikhan Ts., 1990. Report on 1:200000 exploration survey carried out in Bayankhongor, Ovorkhangay and Arkhangay aimags by Galuut group in 1986-1990, №1990 (in Mongolian).

Tomurtogoo, O., 2012. Tectonic subdivision of Mongolian Orogenic Belts. Geological Institute Transaction. 21, 5-25 (in Mongolian).

Tomurtogoo, O., 2002. Tectonic map of Mongolia at the scale of 1:1,000,000 and tectonics of Mongolia (Explanatory notes of the map) Mineral Resources Authority of Mongolia (MRA), Ulaanbaatar, 32 p. (in Mongolian).

Tomurtogoo, O., 2008. Problems in Orogenic structures of Mongol Altay, KhangayKhentei and Mongol-Okhotsk paleo-ocean. Geological Institute Transaction. 18, 9-28 (in Mongolian) .

Ward, J., Mavrogenes, J., Murray, A., Holden, P., 2017. Trace element and sulfur isotopic evidence for redox changes during formation of the Wallaby Gold Deposit, Western Australia. Ore Geol. Rev.82, 31-48.

Wyman, D.A., Cassidy, K.F., Hollings, P. 2016. Orogenic gold and the mineral systems approach: Resolving fact, fiction and fantasy. Ore Geology Reviews. 78, 322-335. 